6. Полушкина А.O. SMART-образование в школах Азии: состояние и проблемы // Вестник РУДН, серия Информатизаџия образования, №2, 2016 2. - C.118-121.

\title{
References:
}

1. Khatuntseva E. A., Dyakova G.S. Procul doctrina et eius progressum in Russia / / Scientifica acta Applicando quaestiones de doctrina infocommunications in scholis superioribus, N. 2, Moscoviae, MTUSI, 2017-p. 42-44.

2. Khlyuneva E.G. Porttitor machinationes enim eget aperire procul educationem per rationem operari cum alumni, qui erudire in familia et correspondentia forma // Informatization de perdurantes educationem2018. Materia Internationalis Scientific Colloquium. Moscow: RUDN, 2018, vol. 2. - Pp. 222-226.

3. Kuzmina A.P. usu procul discendi senior scholárum: quaestiones et spes / / "colloquium erat-acta" N. 10(62), $2020-p .159-161$.

4. Schulman A.H., Sims R. L. Learning in an online format versus an in-class format: An experi-mental study // Technological Horizons in Education Journal. 1999. Vol. 26. pp. 54-56.

5. Murphy T.H. An evaluation of a distance edu-cation course design for general soils // Journal of Agricultural Education. 2000. Vol. 41. pp. 103-113.

6. Polushkina A.O. DOLOR-institutio in scholis Asia: status et quaestiones // Actade RUDN, Informatization Educationis series, N.2, 2016, pp. 118-121.

МРНТИ 14.01.11

https://doi.org/10.51889/2020-4.1728-5496.04

A.K. Zhunussova ${ }^{1}$, A.Althonayan ${ }^{2}$, A.A. Golovchun ${ }^{1}$

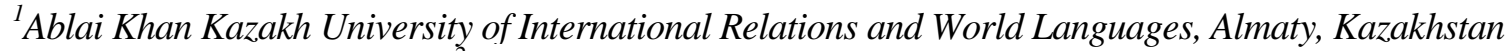

${ }^{2}$ Brunel University London, Great Britain

\section{THE FORMATION OF INTERCULTURAL COMMUNICATIVE COMPETENCE USING MODELLING METHOD}

Abstract

In the article, the modelling is considered as one of the effective methods in the formation of intercultural and communicative competence of students. The FLT system, like any other system, functions and develops in the light of its predetermined goals and planned results, and this regulates the delineation of several subsystems within the parameters of the entire system - in this case, a foreign language education system. The necessity to move away from a narrow book understanding of "foreign languages" towards the general system of foreign language education as a multifaceted area of research has become apparent in the modern era. method

Keywords: foreign language education, intercultural communicative competence, modelling, modelling

$$
\begin{gathered}
\text { А.К. Жунусова }{ }^{1} \text {, А.Алтонаян }{ }^{2} \text {, А.А. Головчун }{ }^{l} \\
{ }^{1} \text { Абыллай хан атындавы Қазақ Хальққаральқ Қатынастар және Әлем Тілдер Университеті, } \\
\text { Алматы қ., Қазақстан } \\
{ }^{2} \text { Брунель Университеті, Лондон, Ұльбритания }
\end{gathered}
$$

\section{МӘДЕНИАРАЛЫК ЖӘНЕ КОММУНИКАТИВТІК КҰЗІРЕТТІЛІГІН ҚАЛЫПТАСТЫРУДАҒЫ МОДЕЛЬДЕУ ТӘСІЛІН ҚОЛДАНУ}

$$
\text { Аңцатпа }
$$

Мақалада модельдеу студенттердің мәдениаралық және коммуникативтік құзіреттілігін қалыптастырудағы тиімді әдістердің бірі ретінде қарастырылады. Шет тілдерді оқыту жүйесі, кез-келген басқа жүйе сияқты, алдын-ала белгіленген мақсаттар мен жоспарланған нәтижелер аясында жұмыс істейді және дамиды және бұл бүкіл жүйенің параметрлері ішінде бірнеше ішкі жүйелердің бөлінуін реттейтін жүйе 
бұл жағдайда - шет тілінде білім беру. Зерттеудің жан-жақты бағыты ретінде «шет тілдерді» кітаптан тар түсінуден жалпы шет тілінде білім беру жүйесіне көшу қажеттілігі қазіргі дәуірде айқын көрінді.

Түйін сөздер: шет тілінде білім беру, мәдениетаралық коммуникативтік құзыреттілік, модельдеу, модельдеу тәсілі

Жунусова А.K. ${ }^{l}$ Алтонаян A. $^{2}$, Головчун А.А. ${ }^{l}$

${ }^{1}$ Казахский университет международных отномений и мировых языков им. Абылай хана, 2. Алматы, Казахстан

${ }^{2}$ Университет Брунеля, Лондон, Великобритания

\title{
ФОРМИРОВАНИЕ МЕЖКУЛЬТУРНОЙ КОММУНИКАТИВНОЙ КОМПЕТЕНТНОСТИ С ИСПОЛЬЗОВАНИЕМ МЕТОДА МОДЕЛИРОВАНИЯ
}

\begin{abstract}
Аннотащия
В этой статье моделирование рассматривается как один из эффективных методов формирования межкультурной и коммуникативной компетентности студентов. Система обучения ИЯ, как и любая другая система, функционирует и развивается в свете своих заранее определенных целей и запланированных результатов, и это регулирует разграничение целого ряда подсистем в рамках параметров всей системы - в данном случае, системы иноязычного образования. Необходимость отхода от узкого книжного понимания «иностранных языков» в сторону общей системы иноязычного образования как многоплановой области исследований стала очевидной в современную эпоху.

Ключевые слова: иноязычное образование, межкультурно-коммуникативная компетенция,
\end{abstract} моделирование, метод моделирования.

Introduction. The term "modelling" is well known in modern science, although it is often used without any reference to its empirical nature as a category for methods of obtaining knowledge and research-based on model building. The most common definition of the term "model" as an artificial construct is the definition of a specialized object created to obtain or store information in the form of a model or description that reflects the characteristics of the original object under study [1, p.158].

Even though modelling as an empirical method of obtaining knowledge was widely used in science and the scientific community and that the twentieth century witnessed the universal recognition of the modelling method as a fundamental method for constructing scientific hypotheses, the modelling method was not based on a general methodology, although its empirical character was outlined in developing the theory of modelling.

Research methodology. The main, generally accepted signs of "modelling" as an empirical method are: 1) modelling is a theoretical and empirical method for understanding complex objects and phenomena; 2) the essence of modelling is the reflection or replacement of real objects, processes and phenomena with similar indicators; 3) analogies reflect the features of a real object in a systematic and interconnected form; 4) the modelling results lead to the creation of a model that allows to obtain new empirical knowledge about the real object under consideration in accordance with general goals; 5) the model, from a structural point of view, is a complex organizational unit, which can also be represented by a system of modules, each of which represents one aspect of the content of the general model; 6) a model is an object for gaining empirical knowledge and a tool for the theoretical transformation of the studied object; 7) the scientific and methodological basis of modelling is the "law of similarity", that is, the presence of uniform corresponding relations between two objects; 8) the final stage of the modelling process is the creation of adequate "control".

If the universal definition of "model" as a tool for acquiring knowledge is understood as a concise or abstract representation of a given object, which in the process of modelling replaces the original, real object. In consequence of which the research results lead to the acquisition of new knowledge about the original object, modelling as a method can be understood as involvement in the process of building, studying and applying models. The structure of the modelling process includes the following specific methods of cognition: 1) the use of abstraction; 2) the use of analogies and their analysis; 3) the formation of conclusions based on the comparison, analogy, forecast and other methods of obtaining knowledge; 4) the formulation of hypotheses. The main requirements for any type of modelling are the presence of three components: the subject (researcher), the object of study (the object that must be studied/modelled), a model for obtaining knowledge about the object of study and which takes into account the relationship between this object and the subject. 
«Modelling as a method of obtaining knowledge is characterized by the systematic nature of the process of acquiring knowledge, the complex nature of the constructed model, the possibility of the practical application of its abstract and logical procedures, universal applicability, the ability to predict the modelled object and the ability to perform functions of both acquiring knowledge and creating forms» [1, p.159].

According to the research of teachers Abdurazova P.A., Raiymbekov Y.B., Daukeyeva A.A the students who studied in the conditions of application of the method of theoretical modelling, there is a gradual increase in the awareness of knowledge. Awareness of knowledge is expressed in the ability to comprehend tasks proposed under the characteristics of awareness (understanding the nature of relationships between knowledge, the difference between essential and insignificant relationships; understanding the mechanism of formation and the manifestation of these relationships; understanding the bases of acquired knowledge; their efficiency; ways of applying knowledge; understanding the available principles underlying these methods of application), and offering close and ideal solutions; To perform tasks on awareness, the student should not possess a large amount of theoretical material at a high level but should be able to apply the knowledge gained by him, which are stipulated in the educational standard. The main skill that has been revealed to reveal in tasks for awareness is the ability to establish links between the studied elements of the content. [3, p.285]

Research results. Academic disciplines and sub-disciplines that study verbal communication (communicative, psycholinguistics, social psychology) have attempted to create a structure or model of communication-based on: - the main types of psychological functions of communication: informationcommunicative, regularly-communicative, affective-communicative (B.F. Lomov); - socio-psychological forms of social interaction and communication related to the setting and implementation of goals: communication as a process of information exchange (the narrow, practical aspect of communication); the interactive aspect of communication in the sense of collective planning and implementation of activities and communication; the perceptual aspect of communication as the processes of acquisition, acceptance and communication of knowledge (G.M. Andreeva, A.A. Dontsova);

In the theory of foreign language teaching, in addition to the intercultural and communicative approach, which has recently had a monopoly influence on the entire system of foreign language education, there is also a method of integrative communication teaching, which is an attempt to model intercultural communication as a controlled process of organizing interpersonal communication. This approach, unfortunately, does not meet the requirements of a conceptually complete theory, since it understands the formation of intercultural communication ability as a process by which students are taught to overcome various "barriers" in communication caused by a "subjective individual", ideas and concerns regarding complexity and unusual nature ... situations " [4, p.141]. Its training system is aimed at overcoming barriers to communication and offers a choice of various types of knowledge about these barriers and a conscious approach to overcoming any obstacles that may arise. The most important tasks in interactive communication training are teaching methods of mutual understanding, such as identification (a means of understanding your communication partner), stereotyping (classification of types of communicative behaviour as indicative of a particular social culture), reflection (recognition of students' progress and learning outcomes), feedback (receipt by the addressee of information about the effect of his message on the addressee, etc.).

This indicates that the interactive approach to teaching communication is focused on the socio-psychological aspects of communication and that the field of linguo-pedagogical research is not clearly defined. This approach, as a method of teaching intercultural communication, does not fit into any aspect of existing theories of teaching a foreign language.

According to the theory of S.S. Kunanbayeva, «a model of communication is a new model of education/communication and a structure that can be transformed and improved. The modelling of communicative situations is aimed at reproducing real communication in the learning process by reflecting the main motivational, substantive, organizational and functional features encountered in various types of situations» $[1, \mathrm{p} .176]$.

There are several stages of modelling situations. At the stages of modelling typical situations, students get acquainted with models that reflect in various communicative spheres all types of possible situations encountered in the context of this profession. In these situations, students listen to native speakers, which is then repeated or used in role-playing games. At the stage of assimilation of content, students develop it independently, with the help of appropriate tips and involving them in changing the circumstances of the main situations and creating new options. At the stage of development of the aspect of training and promotion, students create new variations of 
basic communicative situations that significantly expand the boundaries of the basic model. After a sufficient period of working with models of communicative situations, we propose moving on to the stage of intercultural and communicative communication associated with the profession. At the stage of direct, related to work of communication, the context-communicative stage of the subject content of the student's future profession is implemented.

The methodological principles of modern methods and techniques of foreign language education have been developed at the Kazakh University of International Relations and World Languages and «reflect their intercultural- communicative, cognitive-activity and individual-centredprogramme for the methodology of foreign language education». [2, p.217]

Picture 1 presents "Modelling of a context-based content of communicative complexes (CC) in the formation of intercultural and communicative competencies responsible for the preparatory stage for communication and the stage of direct communication".

\section{The modelling of a context-based content of communicative complexes (CC) in the formation of intercultural and communicative competencies (Table 1)}

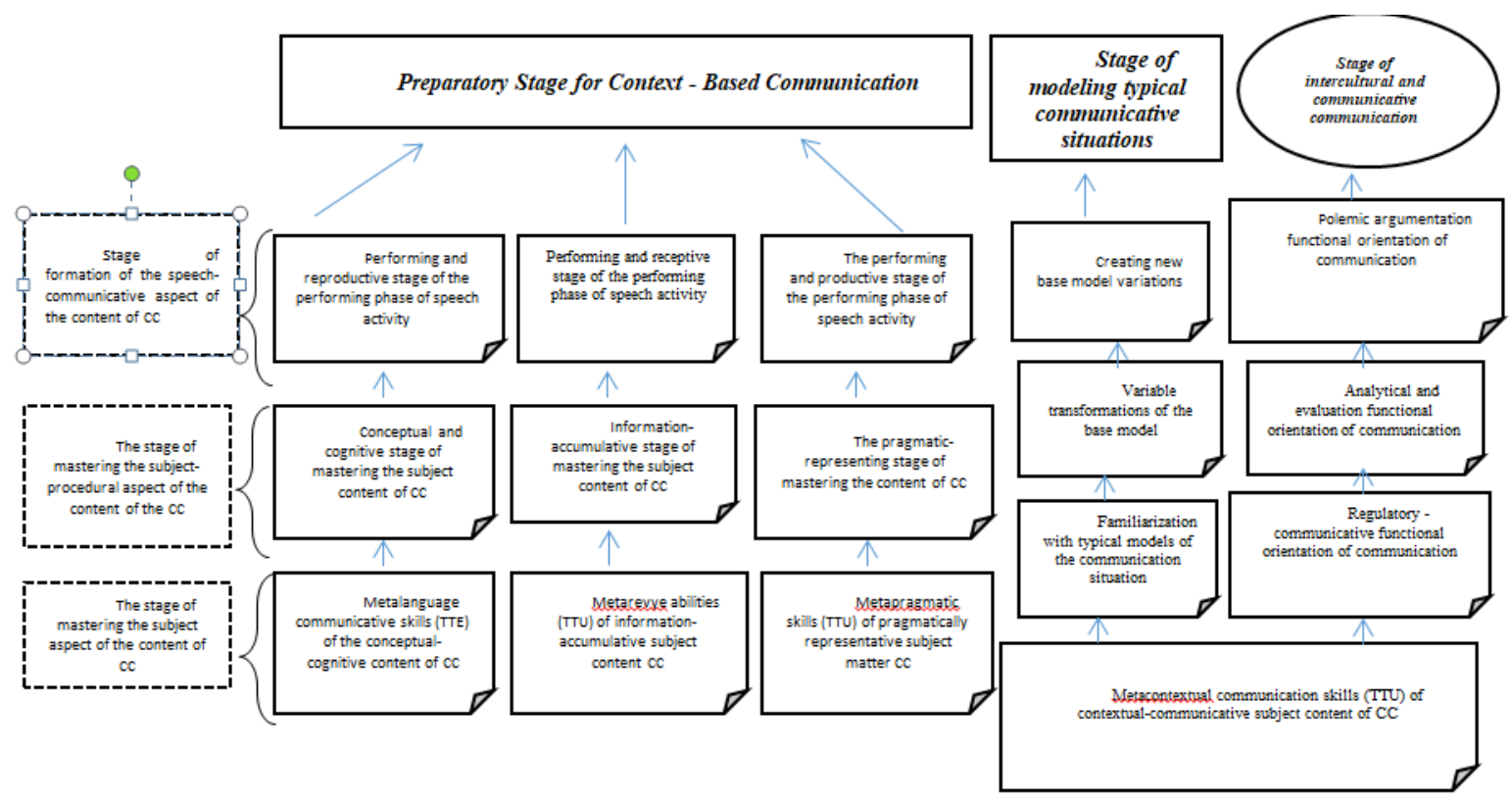

Objects of modelling in foreign language education may include:

- a model of the entire system of foreign language education to formulate the theory and practice of teaching;

- a model of the process of mastering the language (a description of the accounting mechanisms and internal processes of mastering a foreign language);

- methodological model as a training system;

- a communication model as a multi-stage continuum of communicative acts;

- a model of individual communication situations.

It should be noted that to simulate situations to enhance the verbal and cogitative activity, the role of exercises that develop speech skills that have a communicative task adequate to the task of a real utterance is very important.

Let's consider exercises to develop communication skills (situations, business games, individual projects/presentations, role-playing games) at the stage of contextual communication:

1. Prepare and play the following situation: At the meeting of bank directors, the president raised a question for discussion - the bank has exceeded its cash limit, and it wants to invest the latter in such a way that it is both profitable and safe for 1) buying municipal bonds with a yield of $3.5 \%$ (bonds with general obligations that are not taxable) 2) for the purchase of proposals, although there are some doubts about the scale of the return on investment 3 ) for the purchase of shares of the company, which are guaranteed profitable sources of income. 
You, as the president, believe that investing in municipal bonds is the safest option, but some board members are interested in a more obvious profit that can be obtained by buying shares. Support your idea in a short format by predicting opposing views, preparing compelling counterarguments, and providing evidence that will stimulate discussion and move the discussion forward. You can use the following vocabulary list and preliminary discussion dialogue between the president and the board member as a model:

1. cash 2. cash-in-banks 3. Bond 4. Bond issue 5. Diversify 6. The general obligation bond 7. Municipal bond 8. Offering 9. Rate of return 10. Revenue 11. Revenue bonds 12. AA rating 13. Shares 14. Yield 15. Yield interest 16. Tax-exempt 17. Speculative 18. Fluctuation

\section{Exercises on forming the substantive aspects of intercultural and communicative competencies (ICC) (Table 2)}

\begin{tabular}{|c|c|c|c|}
\hline & $\begin{array}{l}\text { Communication } \\
\text { preparing } \\
\text { exercises }\end{array}$ & $\begin{array}{c}\text { Communication } \\
\text { Modelling Exercises }\end{array}$ & $\begin{array}{c}\text { Intercultural } \\
\text { Communicative Types } \\
\text { of Exercises }\end{array}$ \\
\hline $\begin{array}{l}\text { The formation of the } \\
\text { procedural aspect of the } \\
\text { content of CC }\end{array}$ & $\begin{array}{l}\text { Exercises that form the } \\
\text { procedural aspects of } \\
\text { communication in } \\
\text { various types of speech } \\
\text { activity }\end{array}$ & $\begin{array}{c}\text { Creative situational } \\
\text { exercises }\end{array}$ & $\begin{array}{l}\text { Polemic argumentation } \\
\text { functional orientation of } \\
\text { the communication }\end{array}$ \\
\hline $\begin{array}{l}\text { Stage of familiarization of } \\
\text { the subject matter of TTU }\end{array}$ & $\begin{array}{l}\text { Exercises that form the } \\
\text { assimilation of the } \\
\text { subject content of the } \\
\text { communication }\end{array}$ & $\begin{array}{c}\text { Variationally situational } \\
\text { exercises }\end{array}$ & $\begin{array}{l}\text { Analytical and } \\
\text { evaluation of functional } \\
\text { orientation of the } \\
\text { communication }\end{array}$ \\
\hline $\begin{array}{l}\text { Stages of mastering the } \\
\text { subject content of CC }\end{array}$ & $\begin{array}{l}\text { Exercises, providing the } \\
\text { acquaintance meta- } \\
\text { language material }\end{array}$ & Situation type exercises & $\begin{array}{c}\text { Regulatory and } \\
\text { communicative } \\
\text { functional orientation of } \\
\text { the communication }\end{array}$ \\
\hline
\end{tabular}

Example dialogue law

Board member: I notice that our cash and cash-in-banks has been building up above the amount required by

President: I've had the same thoughts and right now there is a new offering of municipal bonds that can be bought at a price that yields $3.5 \%$.

BM. Are they general obligation bonds?

P. Yes, they are. I prefer those to revenue bonds, don't you?

BM. I do. Does this issue have an AA rating?

$\mathrm{P}$. Yes, and they can be had in five- to ten-year maturities. They're tax-exempt you know.

BM. Do you think we might also buy some stocks to keep our portfolio well-diversified?

P. Well, we might but stocks are much more speculative.

BM. Unless we stick to the blue-chip issue, they show less price fluctuation.

Various proposed role-playing games, probable professional situations and educational projects serve as models and allow you to create the subject and social content of future professional activities and model the system of relationships that is characteristic of this activity. Professionally-thematic situations allow us to develop not only professionally-oriented thoughts but also the skills to solve them using means of a foreign language.

Thematic text units (TTU) at the contextual-communicative stage of the development of communication skills, competencies and sub-competencies for free professional communication contain texts that include problem and professional tasks and texts containing information and instructions for solving them. These separate tasks are a way of implementing a foreign language-based teaching technology. They require students to look for additional information, although they are also provided with enough information to complete the assignments. Here are some examples of assignments and texts that contain enough information to complete them. 
Task 1. A foreign customer has been buying from your firm for a year and has honoured your sight drafts on presentation. He is now asking for open account terms with quarterly settlement by B/E. Write two letters, one agreeing to his request and the other asking for an irrevocable letter of credit covering the number of his quarterly requirements.

Task 2.Your firm's representative in an English-speaking country has sent you order and advises you that payment will be made by irrevocable L/C. Reply to the customer. Also, write the customer's letter confirming the order and making payment arrangements.

Task 3.Your bank informs you that a $60 \mathrm{~d} / \mathrm{s}$ bill drawn by you on a foreign customer has been dishonoured without any explanation. Write to the customer and include banking instructions.

Task 4.Write to your bank manager asking him to advance 70 per cent of the value of a consignment of goods you have just exported to a foreign customer.

To perform these tasks, texts are provided that: 1) explain the meaning of the abbreviations, 2) provide information and instructions on the conditions for obtaining certain services. These texts help students find optimal solutions to their tasks related to professional activities.

Text 1 . The abbreviations $\mathrm{B} / \mathrm{E}$ for 'bill of exchange' and $\mathrm{d} / \mathrm{s}$ for 'days after sight' is often used. $\mathrm{D} / \mathrm{P}$ means 'documents against payment', and D/A 'documents against acceptance'.

Text 2.Overseas bills in the UK are known as foreign bills and 252253 those used within the UK as inland bills. A clean bill is one that is not accompanied by shipping documents. A 'sight draft' or 'sight bill' is paid on presentation. In a 'documents against payment' (D/P) transaction, the sight draft is presented to the importer with the shipping documents and the importer pays immediately i.e. 'on presentation' or 'at sight'. A bill paid 'after sight' must be paid within the number of days specified on the bill. Thus, '30 days after sight' means that the bill can be paid up to 30 days after it has been presented.

Text 3. The two main methods used in settling overseas accounts - bills of exchange and documentary credits - involve banks at home and abroad. A bill of exchange can be at sight i.e. payable of presentation or after sight, payable by a stipulated future date. The exporter can send the bill to the importer direct or his bank with the documents and will receive either payment upon presentation or acceptance against the bill. The advantage of a bill is that the exporter can receive the money immediately if the bill is discounted and the exporter can receive the credit if the bill is not a sight draft. The disadvantage is that the bill can be cancelled or not paid on the due date.

Text 4.A bill of exchange is an order sent by the drawer (the person requesting payment) sent to the drawer(the person paying) stating that the drawer will pay the amount shown on the bill on demand or at a specified time. If the drawer accepts the bill he will sign and date it. The bill can be paid to a bank named by the drawer or the drawer can name a bank which will clear the clear. In this case, the bill will be kept in the drawer's bank until it is to be paid. When the bill is due, it is presented to the paying bank. Such bills are said to be domiciled to the bank holding them.

The above set of exercises develops the preparatory stage of context-oriented communication and allows you to go to the stage of modelling typical situations and variations within the basic model of situations. The creators and adherents of the cognitive-linguocultural methodology of foreign language education have proposed various sets of sequential actions that prepare modelling situations, but preserve the logic of having a single common algorithm for going through the steps for modelling typical situations and their variations. So, for example, when researching and formulating intercultural and communicative competence in the field of commercial international communicative activity (A.B. Tynyshtykbaeva) - the so-called commercial-communicative stage of training includes a sequence of levels that simulate real communication, namely: 1) acquaintance with a model (dialogue) corresponding to a standard (typical) situation, as well as its analytical preparation and understanding using a series of communicatively-oriented exercises, 2) strategic development and tactical skills for each standard model of the situation, 3) modelling of situations such as the standard for the development of flexible professional communication skills. 4) business and professional games to illustrate the achieved level of communicative and professional competence.

Discussion. Thus, the model as an object for gaining knowledge and a tool for transforming the original (or research) object allows you to realize the main functional goal: using the similarity law to establish uniform corresponding relations between two objects to acquire knowledge about the original object, based on abstract and logical mental processes. Modelling is characterized by features based on activities, transformations and processes, which are especially important for deciding whether it can be applied in communication theory [1, p.160].

It should be noted that the idea of modelling the situation to the formation of intercultural and communicative competence is the most unusual, maybe even unique. This can be explained by the complexity of diversity since the number of verbal processes found in the course of social interaction is so great that it is difficult to predict. Therefore, the modern interpretation of the concept of "communication" is dominated by a socio-psychological 
analysis of the system of interpersonal and social communication, since a very complex system of connections connecting a person with the outside world is manifested through the intercultural communication.

The legitimacy of the definition of communication as the implementation of the entire system of human relations is also confirmed by the fact that human society itself is unthinkable outside of communication, which acts in it as - a means of uniting people; - as an environment for personality development during social relations (at the micro-level); - as a social environment in which an individual unites with others through interpersonal relationships and communication (at the micro-level); - as a secondary social category related to the system of social interaction in the context of the primacy of social relations (interpersonal and social), since verbal communication is generated by the system of social relations that exist between people. This socio-psychological approach is justified not only by the active nature of communication but also by the idea of synthesizing activity and communication - the leading concept of Soviet psychology. After all, collective activity, whether intellectual or work-related, takes a combined form of collective activity and communication, and therefore these two concepts must be analysed in unison.

However, accepting the essential unity of "activity" and "communication", the researchers did not come to a consensus on the nature and status of their relationship. There are three main views: 1) "activity" and "communication" are two parallel aspects of social life that are interconnected as processes; 2) "communication" is a special element of "activity", while "activity" creates the conditions for "communication"; 3) "communication" is a special type of "activity" ("communicative activity"). In addition to these views, which are based on the assignment of different roles to two concepts, others support - a broader interpretation of the unity of the two concepts, where communication and the aspect of collective activity are a special derivative of common activity. This raises communication to the level of the most important aspect of activity - verbal and cogitative, while the activity itself is defined as objective content since its essence and function are manifested through the content of the communication. From this point of view: 1) communication is included in all types of activities 2) communication plays the role of organizing, generalizing and planning activities, as well as other characteristic functions, such as studying, influencing, etc.

It is worth paying attention to the study shown by Tran, T.Q., Duong, T.M. that the ICLT (Intercultural communicative language teaching) model as one of the productive models was seen as an effective form of intercultural language education to facilitate the achievement of learners' intercultural communicative competence; (both language competence and intercultural competence). Generally, both the learners' language competence and intercultural competence developed in a similar pattern, which indicates that learners can learn intercultural content through language content and vice versa. This study might suggest that in a long term the ICLT model can equip learners with intercultural communicative competence to become intercultural speakers who can be fluent in a foreign language and function appropriately and effectively in the context of globalization. However, there should be radical changes in teaching methodology which shifts its current approach to intercultural language approach. The ICLT model should be experimented at various educational levels in different contexts to further confirm the effectiveness of this model. Additionally, different supportive factors on learners' ICC development should be scrutinized to facilitate the process of learners' intercultural language learning [5].

Conclusion. As a result of this, it is correct to begin modelling the educational process with stereotypical communicative situations that reflect sociocultural or linguocultural models of cooperation between people that are characteristic of representatives of a particular socio-and linguistic culture. "Communicative situation" as an integral component of intercultural communication has all its inherent characteristics and characteristics of intercultural communication. Since the process of intercultural communication can be represented as a sequence of communicative acts to facilitate cooperation between communicators, as already mentioned, an individual, the specific communicative act is still able to reflect the characteristics of the entire communication process. This means that the simulation can occur within the reduced parameters, while at the same time still corresponding to the original object as a whole.

\section{References:}

1. Kunanbaeva S.S. Modern foreign language education: methodology and theory. - Almaty, 2005. - $262 p$.

2. Kulibaeva D.N. An innovative model for the formation of internationally standard levels of foreign language proficiency in international schools. - Almaty 2002. - $216 \mathrm{p}$.

3. Abdurazova P.A., Raiymbekov Y.B., Daukeyeva A.A. Theoretical modelling as a method of developing the awareness of students' knowledge in chemistry classes in high school // Bulletin of Kazakh national pedagogical university after Abai, Series «Pedagogical sciences» №1 (61), 2019. - 402 p.

4. Geykhman L.K. Interactive teaching of communication as a model of intercultural communication. $\$ Vestnik MSU. Series 19. Linguistics and intercultural communication. - 2003. - No. 3.

5. Tran, T.Q., Duong, T.M. The effectiveness of the intercultural language communicative teaching 
modelfor EFL learners. Asian. J. Second. Foreign. Lang. Educ. 3, 6 (2018). PubMed Central and Web of Science (Clarivate Analytics).https://doi.org/10.1186/s40862-018-0048-0

6. The Law on Education of the Republic of Kazakhstan. No. 389-13 of the Republic of Kazakhstan. 06/07/99. Astana city.

7. The concept of development of education of the Republic of Kazakhstan for 2015 on 04.11.2004.

8. The concept of development of foreign language education of the Republic of Kazakhstan. Almaty, 2004.

9. The concept of language education of the Republic of Kazakhstan (draft). - Almaty, 2010

10. A model program for the practical course of the main foreign language. - Astana, 2003

11. Andreeva G.M., Yanoushek Y. The interrelation of communication and activity. Communication and automation of joint activities. - M.,1987.

МРНТИ 14.01.21

https://doi.org/10.51889/2020-4.1728-5496.05

\author{
M.М. Зұлпьххарова ${ }^{1}$, Г.Т. Сәдуақас ${ }^{1}$, М.Ж. Сұлтанбек ${ }^{2}$ \\ ${ }^{1}$ Абай атындавы Қазақ ұлттық педагогикалық университеті \\ ${ }^{2}$ K.Ясауи атындавы Халықаралық қазақ-түрік университеті PhD, ава оқытушы \\ Түркістан қ., Қазақсттан
}

\title{
«АКАДЕМИЯЛЫҚ ДАРЫНДЫЛЫҚ» ҰҒЫМЫНЫН ТЕОРИЯЛЫҚ АСПЕКТІЛЕРІ
}

\begin{abstract}
Аң̧датпа
Мақалада «академиялық дарындылық» ұғымының генезисі, даму ерекшеліктері сипатталады. «Академиялық дарындылықтың» философиялық категориялары: интеллект; акт; қабілет; ойлар мен мадақтар жолы; даналық; адамдарға қатысты айырмашылық; жоғарғы идеялар; монадалар; диадалар; триадалар пайымдаушылық; шығармашылық белсенділік; «вегетативтілік»; «сезімдік»; «рационалдық»; жетік бақыт, дианоэтикалық ізгілік; ойланушының көптілігі (дуальдылығы); ішкі даму; генерация динамикасы; өздігінен дамитын және атемпоральды болмыс ғылыми түсініктеріне талдау жасалады. Сонымен қатар психологиялық білім бойынша категориялары: керемет меңгеру қабілеттілігі; оку қабілеті; туа біткен қасиеттер; нақты қатынастардың жеке конгломераты; жоғары интеллект; жылдам ойлау; креативтілік; талант; дана(мінез-құлық) түсініктеріне сипаттама беріледі. Мақалада интеллектуалдық танымдық дамудың жоғары шегі; терең білім алу; қалыптан тыс табысты нәтижеге жетуге бағытталған іс-әрекеттің жоғары деңгейі; пәндер мен қызмет түрлеріне ерекше қабілеттер; пәндік мазмұнды түсінуге жоғары бейімділік түсініктері педагогикалық тұрғыдан «академиялық дарындылықтың» мазмұнын құраушылар ретінде баяндалады.

Мақалада диагностикалық жұмыстар жайлы талданады. Айқындау экспериментінің мақсат, міндеттері, оның ұйымдастырылу алгоритмі ұсынылады. Айқындау эксперименті «6В01301-бастауыш білім беру бағдарламалары» бойынша білім алушыларға А.И. Савенковтың «Дарындылық картасы» әдістемесінің негізінде жүргізілді. Сауалнама арқылы студенттердің академиялық дарындылығы АКТ, музыка, көптілділік, бизнес-инновация сфералары бойынша анықталып, оның нәтижелері беріледі. Ғылыми-әдістемелік ұсыныстар дайындалды.
\end{abstract}

Түйін сөздер: дарындылық, академиялық дарындылық, академиялық үлгерім, креативтілік, шығармашылық белсенділік, интеллектуалдық танымдық даму, жеке конгломерат, талант, монада, диада, триада.

\footnotetext{
Зулпьхарова М.M. ${ }^{1}$, Садуакас Г.Т. ${ }^{1}$, Султанбек М.Ж. ${ }^{2}$

${ }^{1}$ Казахский наииональный педагогический университет имени Абая, 2. Алматы, Казахстан

${ }^{3}$ Международного казахско-турецкого университета Ходжи Ахмеда Ясави
} 